\title{
Institution reinforcement of mosque in social economic empowerment of small merchants community
}

\author{
Alfiana Yuli Efiyanti ${ }^{1 *}$, Muhammad Ali ${ }^{2}$ and Saiful Amin ${ }^{1}$ \\ ${ }^{1}$ Universitas Islam Negeri Maulana Malik Ibrahim Malang, Indonesia \\ 2Universitas Hamzanwadi, Lombok Timur, Indonesia \\ *Correspondence email: alfi_huda@pips.uin-malang.ac.id
}

\section{ARTICLE INFO}

- Research Article

Article History

Received 6 March 2021

Accepted 28 May 2021

Published 2 October 2021

\section{Keywords}

empowerment; institution reinforcement; mosque; small and medium enterprise; social value

\section{JEL Classification}

A13; 015; Z12

\begin{abstract}
Historically, mosque is the center for human civilization with various activities covering social, economy, and culture. However, its function have been shifted and specialized into a place of praying. This paper aims to describe the contribution of the Great Mosque of Attaqwa Pancor in social economic empowerment, particularly small businesses in Pancor, East Lombok, West Nusa Tenggara (NTB). The data were collected through observation, interview, and document study. The result of the analysis shows that mosque involvement in the small-scale economic activities has freed them from the difficulty of getting capital access and from dependence. In the first stage, from 2019 to August 2020, through Mawar Emas program, as many as 80 small-merchants in Pancor village were helped to be free from debt. The Great Mosque of Attaqwa with the support of Indonesia Sharia Economic Community (Masyarakat Ekonomi Syariah, MES) successfully distributed the total amount of 80 million rupiahs for the small business purposes. The existence of the Attaqwa Mosque proves and affirms that religious institutions can contribute to the social economic development. Considering the strategic position, this paper suggests the need for institutional reinforcement so that mosques to restore their broader role in fields other than religious affairs.
\end{abstract}

To cite this article: Efiyanti, A. Y., Ali, M., \& Amin, S. (2021). Institution reinforcement of mosque in social economic empowerment of small merchants community. Journal of Socioeconomics and Development, 4(2), 189-197. https://doi.org/10.31328/jsed.v4i2.2272

ISSN 2615-6075 online; ISSN 2615-6946 print (C)WG Press, 2021

\section{INTRODUCTION}

Under the leadership of Prophet Muhammad and the subsequent Chalips, mosques served as the center of civilization. All political and socio-economic activities were organized in the mosque. Dynamics of life and human problems were discussed and resolved at the mosque. However, in Indonesia today, the role of mosques is slowly diminishing. Activities in mosques are dominated by religious activities such as religious rituals implementation and religious discussions (Jannah, 2016). To return to their prior designated nature, several mosques try to expand their functions like those in the era of Prophet Muhammad. They mainly carry out empowerment to strengthen society's socio-economic condition (Musahadi, 2018). A mosque in Jepara, for instance, has played a role in reducing the socio-economic impact of the COVID-19 pandemic (Ilmi \& Alhakim, 2020). The function of mosque as a center of social economic development has been wellknown, yet the mechanism of the religious institution involvement to make a huge impact on social welfare improvement is not widely exposed. The study of 
Saint-Blancat \& Friedberg (2005) in Europe showed that the employment of mosque as the center for nonreligious-related activities is controversial. Many of them argued that mosques can be abused if they also concern non-religious-related issues (Pierce, 2014). The considerable contribution and public acceptance on the role of mosques need to be studied carefully.

Studies on the function of mosques indicated that mosques are seen as a religious learning or education center (Riwajanti, Muwidha, \& Candrawati, 2017). Even, a hadith that tells Moslems to "vitalize the mosque" is interpreted as performing more religious rituals. A research by Haqqoni (2020) on the function of a mosque other than a place of religious activities suggested that it has been used as a community health center (Haqqoni, 2020). The relationship between mosques and economic activities can be found in the study by Al-Krenawi (2016), Astari (2014), Riwajanti et al. (2017), and Wulandari (2017). In addition to exploring how mosques become social movements supporting societies' economic activities through capital funding, those papers also discussed the social networks which strengthen the institutional power to access economic resources. In Pancor Nusa Tenggara Barat, Attaqwa, a mosque with sacred values as a place of religious rituals, plays a substantial role in increasing social welfare. Supported by Indonesia Sharia Economic Community (Masyarakat Ekonomi Syariah, MES), the mosque runs a program to help merchants solve social-economic problems. A group of small-scale merchants with very limited capital in that district can successfully develop and secure the family welfare due to the mosque's assistance.

This research aims to complement the shortcomings of the existing studies by analyzing how the welfare of small-scale merchants can be achieved through religious institution approach. It specifically examines how mosques perform the function of community empowerment through institutional approach. This paper also shows that empowerment covers not only capital support for business expansion but also institutional strengthening to open up access for small-scale merchants to develop.

The latter is based on the argument that the economic development of small-business groups may not be achieved without any access expansion. The small-scale merchants will never make changes without an intermediary structure that bridges them into economic resources (Richter, 2019). Religious institutions can serve as intermediary structures that provide mentoring to guarantee the small-scale merchants' success in running the business.

\section{RESEARCH METHOD}

An in-depth study towards the Great Mosque of Attaqwa, Pancor, East Lombok, West Nusa Tenggara (NTB) province of Indonesia was conducted. The nature of the mosque as the center for human civilization has proven to provide a solution for the problems in the society through a program called Mawar Emas (Golden Rose). Mawar Emas is the abbreviation for Melawan Rentenir Berbasis Masjid (Fighting Moneylenders with Mosque). To run the program, the Great Mosque of Attaqwa is supported by Sharia Economic Society (Masyarakat Ekonomi Syariah/MES) that consists of NTB Syariah Bank, universities, and the provincial government.

This study employs a qualitative approach. The required data were obtained through interview, observation, and document study. The interviewed informants were selected based on their direct involvement in the cases studied. The respondents consisted of the Head of MES East Lombok District as the technical executive, NTB Syariah Bank as the provider of funds, and small-scale merchants in Pancor as the subject of the Mawar Emas program. Other informants represented universities and mosque administrators (takmir) who help supervise merchants (Table 1).

Table 1. Research Respondents

\begin{tabular}{clc}
\hline No. & Respondents & Amount \\
\hline 1 & Head of MES & 1 \\
2 & Officer of NTB Syariah Bank & 1 \\
3 & Lecturers of Universitas Hamzanwadi & 2 \\
4 & Lecturers of Universitas Nahdlatul Ulama & 2 \\
5 & Takmir of Attaqwa Mousque & 1 \\
6 & Small merchants involved on Mawar Emas & 80 \\
$\quad$ Program & \\
$\quad$ Total informants & 87 \\
\hline
\end{tabular}

The interview with the MES and the NTB Syariah Bank aimed to obtain data regarding their role in providing support for institutional strengthening to the takmirs. Interviews with academics from universities and mosque takmirs strengthened the data about the Mawar Emas mentoring program. Whereas, the smallscale merchants provided information about their conditions before and after participating in the program. 
To support the results of the interview, the documents associated with the Mawar Emas program were studied carefully. They included program planning, a list of merchants who participate in the program, and notes on their involvement with the high-interest loan. In addition, the situation of the merchants, the implementation process of the Mawar Emas program, and the impact of the programs were carefully observed. In order to obtain comprehensive and in-depth data, the researcher lived with the subjects of the study for 10 months, from December 2019 to November 2020.

Descriptive analysis was then used. The unnecessary parts were reduced while the necessary ones were classified according to their types and chronologies. Next, they were described, analyzed, and presented.

\section{RESULT AND DISCUSSION}

\section{The Condition of the Small-scale Merchants}

The Great Mosque of Attaqwa was established in 1976. It is located at a shopping complex in Pancor Village, Selong District, East Lombok Regency, NTB. Its worshippers are more than 200 people. They include farmers and small merchants around that area (DKM Masjid Attaqwa, 2020).

This study involved 80 small merchants with more than 5 years of working experience. They were found around Pancor market and across the streets. Due to limited funds, it was hard for them to develop their business. Even, many of them were stuck with loan sharks. The income had hardly met their daily needs for years and was even sometimes insufficient. Based on the business types and locations, the small merchants were divided into 5 categories: greengrocers, grocers, traditional snacks sellers in the market, food vendors along the streets, and vegetable pedlers around the village of Pancor (Table 2).

The difficulty of small merchants to meet their daily needs led them to borrow money from fund providers which were nearby, easy to reach, and very accommodating. Nearby means that the providers were located around them. The providers were easy to reach as they were willing to come to the merchants who need loan. They lent money to the small merchants with various amounts, ranging from 500,000 to $3,000,000$ rupiahs. Such loan providers were called "Bank Subuh" by locals as they would usually collect the loan payment at daybreak. In Indonesia, this type of lenders is typically called "rentenir", in which the payment system creates a heavy burden for the debtors (Nasrulloh, 2020). The simple process encourages the small-scale merchants to get loan from those lenders. In the case of "Bank Subuh" in Pancor, the ease of the loan disbursement was granted without any condition, as basically they knew each other. However, this ease should be paid off with high interest, which was $2 \%$, that must be paid daily. If the loan principal could not be paid off immediately, the debtor must pay daily interest.

Merchants were heavily burdened with interest payments on loans, which induced them to borrow more. At the beginning, the merchants variously borrowed from 500,000 to $3,000,000$ rupiahs. It then happened over and over again so that the loan principal got bigger, while the installments and interest were also higher. Rohmiati Jalilah, one of traditional snacks sellers, could not be free from debt which got higher. She and the other small merchants could no longer think about business development but were more preoccupied with the way to repay the loan. This condition commonly happens until debtors face a debt-trap condition (Rahoyo \& Nss, 2019).

Bank is the authorized financial institution that provides funding programs for micro, small, and medium-sized businesses (Diana, 2019). However, not all small merchants could access the funds in the bank. The few numbers of small merchants who access the banks' funding assistance were caused by internal and external factors.

Table 2. The Business Type of Small Merchants in Pancor, 2019

\begin{tabular}{|c|c|c|c|c|c|}
\hline No. & Business Type & Location & Sample size & Percentage & Monthly Average Return \\
\hline & & & & $\%$ & rupiah \\
\hline 1. & Greengrocer & Pancor Market & 24 & 30 & $3,000,000$ \\
\hline 2. & Grocer & Pancor Market & 19 & 24 & $3,250,000$ \\
\hline 4. & Street vendor & The streets of Pancor & 13 & 16 & $2,750,000$ \\
\hline 5. & Vegetable pedler & Pancor village & 8 & 10 & $2,750,000$ \\
\hline
\end{tabular}


An internal factor was their inability to provide the collateral required by the bank. The collateral could be in the form of a certificate of vehicle ownership, home/land certificate, cash flow, the financial statements of the business, and so on. Misram, a chicken noodle vendor, stated that he never knew the physical form of the letters of guarantee required by the bank. Another internal factor was the low level of the merchants' formal education, making them unable to fulfill the administrative requirements imposed by bank, such as filling forms or writing statements. The external factor was the incomplete information received by merchants, resulting in their reluctance to access the fund. Therefore, the existence of banks and any other formal financial institutions in collaboration with communities is a must (Bustan, Divianto, \& Setiawan, 2017).

Table 3. The Development of Small Merchants' Turnover in 2016-2018

\begin{tabular}{llcc}
\hline No & Business Type & Stagnant & Decline \\
\hline & & $\ldots \ldots \ldots . . . \%$ & $\ldots \ldots \ldots .$. \\
1. & Greengrocer & 80.0 & 20.0 \\
2. & Grocer & 83.3 & 16.7 \\
3. & Traditional snack seller & 90.0 & 10.0 \\
4. & Street vendor & 87.5 & 12.5 \\
5. & Vegetable pedler & 80.0 & 20.0 \\
\hline
\end{tabular}

During 2016 - 2018, 80\% to $90 \%$ of merchants' businesses were in stagnant condition while the remaining merchants' businesses (10 to 20\%) indicated a declining turnover (Table 3).

\section{Empowering Small Merchants}

The Great Mosque of Attaqwa Pancor is one of the mosques in Indonesia which performs a real action to help small-scale merchants solve their problems. From the end of 2019 to 2020, the mosque received funding from the Regional Board of MES in cooperation with the provincial government to strengthen the takmir institution of the mosque through various education and training activities. They were included in a program called Mawar Emas. Society empowerment by mosques proves that mosques' role is not only as a worship institution, but also taking care of society problems (Faizaturrodhiah, Pudjihardjo, \& Manzilati, 2018).
The idea of Mawar Emas program was initiated by the Governor of NTB. It was then followed up by the local government, NTB Syariah Bank, Universitas Hamzanwadi and Universitas Nahdlatul Ulama. Through the program, the takmir of the Great mosque of Attaqwa Pancor was reinforced in the knowledge of (i) the role and function of mosque in Islamic civilization, (ii) operational management regarding financial management, (iii) the benefits of bringing mosque prosperous through economic and Islamic approach, (iv) social economic empowerment, (v) the potential of the social fund of Islam in improving the economy of society, and (vi) the introduction of a digital application to manage the mosque finances (DKM Masjid Attaqwa, 2020). Through the reinforcement, the mosque performed a real action in helping merchants overcome the capital issues.

The assistance program for small merchants by the mosque was planned in 2018 and has been implemented since the end of 2019. Recently, the mosque helped to empower 80 small merchants who had debts problems with informal loan providers such as "Bank Subuh". The main action of the mosque to strengthen their economy was reorganizing the merchants into groups. The grouping is intended to strengthen some individuals incorporated in capital management (Hadiyanti, 2008). It can also facilitate the formation of small-business networks and widen their linkage to other businesses. The group consisted of 8 - 20 members based on their business type. Microfinance-based groups have the potential for social capital. This can strengthen the intention and behavior to increase the commitment to repay their loan (Machfudz \& Kamila, 2019).

Takmir, in cooperation with MES, provided mentoring for the merchants who get funding. The mentoring was held every week in the form of preaching. The topic of the preaching was not limited to the religious materials but training and feedback. The training materials were not only about religious issues, but also business ethics in Islam, product development, marketing, business management, and simple financial record. The feedback discussed was about the utilization of the funds that have been given. Within the weekly meetings, the merchants also paid off the loan as agreed. 
Table 4. The Loan Installments, Phase I 2019 - 2020

\begin{tabular}{lccccc}
\hline Small Merchant Type & Group & Number respondent & Loan per Group & Return Period & On schedule return \\
\hline & & people & rupiah & week & $\%$ \\
Greengrocer & I & 12 & $12,000,000$ & 40 & 100 \\
& II & 12 & $12,000,000$ & 40 & 100 \\
Grocer & I & 10 & $10,000,000$ & 32 & 100 \\
& II & 9 & $9,000,000$ & 40 & 100 \\
Traditional snack seller & I & 16 & $16,000,000$ & 40 & 100 \\
Street vendor & I & 13 & $13,000,000$ & 40 & 100 \\
Vegetable pedler & I & 8 & $8,000,000$ & 32 & 100 \\
Total & & 80 & $80,000,000$ & & \\
\hline
\end{tabular}

\section{Empowerment through Funding Assistance}

The mosque institution has a chance to empower the congregation and the local communities. The mosque management as an empowerment agent then manages the funds for productive activities (Utama, Fitrandasari, Arifin, \& Muhtadi, 2018). The empowerment given by the mosque to the merchants is in the form of funding assistance, as it is the most important aspect of small business. Therefore, capital access can be one of the strategies to ensure the small scale economic business is sustainable (Rahim, 2018).

The funding assistance was given based on a group. The installment was made weekly with a joint responsibility system. Joint responsibility means shared responsibility within a group. If one member cannot afford to install the loan, the other group members do a joint venture to pay off. The installment will not feel burdensome as it becomes the responsibility of many members.

The first stage of the loan capital was given in September 2019. The amount was 1 million rupiahs with $0 \%$ interest per individual, and it was given through the group. The recipient of the capital began to pay off weekly in the second month after receiving the loan. The amount of the installment was according to the borrower's financial condition with varying installment periods. Hayatin Nupus could afford paying 25 thousand rupiahs per week, so all the loan can be paid off 40 times or 40 weeks. If the group is successful in repaying the loan according to the contract agreement, they are allowed to propose for a greater amount of funding in the next stages. The success of the capital assistance through the program of the mosque is measured by the ability of the merchants to timely return the loan (Table 4).

Table 4 shows that since its opening in the end of 2019 to the mid-2020, the capital assistance for small merchants has proven merchants' ability to return the loan on schedule. According to takmir of the mosque, the timely return installment that was launched in the first stage loan indicated the smoothness of the businesses run by the capital recipients. Therefore, all merchants currently receiving the loan are on progress to receive subsequent loans after all the loans are paid off. All group members stated that Mawar Emas program helped them gain access to capital without complicated requirement and suffocating interest. Although they are not yet a hundred percent free from the previous Bank Subuh high-interest loans, Saenah hoped that Mawar Emas program would run smoothly so that she can be free from being entangled in debt.

The institution of the mosque can be a structural force that allows access extension in countering against the trap of the market economy (Amalia, 2012; Assari, Mahesh, Emtehani, \& Assari, 2011; Cholil, 2016). The function of mosques in Indonesia have been limited to the center of worship and other religious activities. Meanwhile, its function for other, non-religious issues reflects how it was used during the leadership of Muhammad, in which it also served as a center for education and government administration (Riwajanti et al., 2017). During the era of the caliphs, its function was expanded to be the center for socio-economic activities through Baitul Maal, which managed the collection and distribution of zakat (Riwajanti et al., 2017; Utama et al., 2018). Mosques as a source of capital assistance for small merchants is a historical continuity upon the best practice in the Islamic civilization.

The Great Mosque of Attaqwa Pancor performs a new phase of society awareness on economic empowerment. Social economic empowerment in Indonesia occurred at least in 1905, which began with the establishment of Sarekat Dagang Islam. Sarekat Dagang Islam has become the basis for social economic power in which mosques became the strategic center for the prosperity of people since then 
(Sager, 2014; Siam, 2012). Nevertheless, this movement was then protracted for political purification. Religion also went against the nonreligious movements enacted under religion. Markets, despite being a place for the grassroots to survive, were under the authority of the kingdom which opened up concessions to the Chinese businessmen.

This paper, in addition to reviving the discourse of religious institutional role, also gives awareness of the importance of intermediaries structure (Richter, 2019) to build a small scale economy. This study shows that small merchants through the mediation of the mosque's role have succeeded in removing the problems of the market economy that plunged them.

\section{Research Implication}

Research findings show that mosque as a religious institution has a very important role for the surrounding community. The role must be optimized as done by the Great Mosque of Attaqwa Pancor and supported by MES. This study shows that the mosque functions as an intermediary that connects merchants with the economic resources (Sochimin, 2016; Utama et al., 2018) and enables a source for venture capital to merchants (Omar, Hussin, \& Muhammad, 2017).

The approach which positions the mosque as a part of an integrated social system allows the possibility of discovering its great potential. Its nature, which was the center of civilization in Islamic tradition, returns due to the demand for the grassroots' economic condition which required an alternative approach to resolve. Conventional approaches through various programs of poverty alleviation have been unable to develop and empower small merchants who are trapped in poverty and dependence. The return of the mosque function as a social and economic institution widely known in Islamic civilization has affirmed the need for its development so that it is optimally exposed. This paper also confirms the importance of further analysis about the history of mosque in leading moslems' socio-economic development. Thus, the results of this study provide important implications for several parties.

First, empowering small merchants. By joining the Mawar Emas program, the merchants acquire knowledge and skills related to business development through various kinds of training which are scheduled once a week. In addition, it also raises merchants' awareness in obtaining a business capital loan. They are expected to no longer be tempted by irresponsible lenders or loan sharks, which in this case are more often called "Bank Subuh." The ease of access to loans no longer attracts merchants if the interest system and payment methods are burdensome. Moreover, the existence of a mosque is no longer seen as only a place of worship but also a religious institution that cares for the needs and welfare of the congregations and surrounding community. The relationship between the mosque and the merchants is increasingly intense covering the socio-economic aspect and broader aspects.

Second, mosque institutional improvement. The success of Mawar Emas program proved that the mosque can be a solution for small merchants who have debt problems in "Bank Subuh". It is common to see small businesses with the issue of the tendency to be stuck in the loan trap, instead of limited capital (Mohsin, 2013). The involvement of the mosque can be an institutional backup that empowers merchants' group. The success of Attaqwa Mosque through their first stage of loan beginning in September 2019 encouraged the takmir to prepare the next stages properly in which the second stage was conducted on August 2020. Therefore, Attaqwa Mosque strengthens its relationship with MES and ensures the sustainability of surrounding community empowerment. The next stage was planned to reach a wider range of people in need around the mosque.

Third, strengthening cooperation and networking within MES organizations. MES consists of parties who support and care for small scale business. MES brings together the potential of organizations such as NTB Syariah Bank, Hamzanwadi University, Nahdlatul Ulama University and local government. It supports Attaqwa Mosque and its Mawar Emas program in terms of finance, community education, and strengthening of mosque institutions. Later, it needs to expand more targets to other mosques by increasing the amount of loans disbursed. As such, this study reaffirms the prominence of religious relations with the economy (Kuznetsova \& Round, 2014; Martens, 2014). The scientific discourse about the relationship of religion and economy stuck in the early 1990s (Abdullah \& Aini, 2017). Religion is involved more with political discourse rather than the economic one so that moslem welfare gains less attention. Thus, supporting mosques to be society's economic boost becomes MES's primary concern.

Fourth, the results of this study can also have implications for how local governments take the 
initiative. This study shows that local governments can consider making policies that support the program to expand the institutional role of mosques. Local government initiatives together with MES are encouraged more clearly to develop programs needed to solve economic problems around mosques.

\section{CONCLUSION AND SUGGESTION}

The Great Mosque of Attaqwa Pancor, East Lombok showed its role as an intermediary between small merchants and capital resources. Through Mawar Emas program from September 2019 to August 2020 in stage I, the mosque provided loans to 80 small merchants with the loan worth 80 million rupiahs, using an interest-free scheme. The program will continue to the next stage for further business development and settlement of debts to moneylenders. The structural institutional reinforcement of the mosque gains supports from MES. Cooperation between mosques and MES must be synergized to maintain program sustainability, provide community assistance programs, and foster the empowerment of small-scale merchants.

The study enriches the scientific reference about the existence of a mosque within complex entities yet limited only in a single region issue. A more comprehensive and comparative study is needed to understand how mosque culturally and structurally provides a basis for the strategic roles. In line with that, further research concerning the characteristics of particular region is needed because every mosque and community has its own specific culture. Furthermore, a historical approach is also necessary to examine the ups and downs of the position and role of the mosque besides religious ritual issues.

The research suggests many implications to strengthen small scale businesses around mosques. Firstly, mosques need to ensure that their existence supports social economic empowerment movements and functions more than a place for worship. Secondly, mosques need to strengthen the vision which emphasizes their function for the benefit of society. Thirdly, MES as a party that supports the mosques' social empowerment programs should strengthen and widen its networking. Finally, local governments must show a high commitment to protect small merchants and the poor from the perpetrators of the illegal loan practice.

\section{REFERENCES}

Abdullah, M. Y. M., \& Aini, Z. H. (2017). The Efficiency model of mosque management for the indigenous community in Selangor. Jurnal Hal Ehwal Islam Dan Warisan Selangor, 1(1), 11-19. Retrieved from http://jurnalselangor.com.my/bil-1.-no.12017.html

Al-Krenawi, A. (2016). The Role of the mosque and its relevance to social work. International Social Work, 59(3), 359-367. https://doi.org/10.1177/0020872815626997

Amalia, F. (2012). Implementasi etika bisnis islam pada pedagang di Bazar Madinah Depok. Prosiding Seminas Competitive Advantage, 1(2), 1-6. Retrieved from http://journal.unipdu.ac.id:8080/index.php/semin as/article/view/134

Assari, A., Mahesh, T. M., Emtehani, M. R., \& Assari, E. (2011). Comparative sustainability of bazaar in iranian traditional cities: Case studies in Isfahan and Tabriz. International Journal on "Technical and Physical Problems of Engineering" (IJTPE), 3(9), 18-24. Retrieved from http://www.iotpe.com/IJTPE/IJTPE-2011/IJTPEIssue9-Vol3-No4-Dec2011/3-IJTPE-Issue9-Vol3No4-Dec2011-pp18-24.pdf

Astari, P. (2014). Mengembalikan fungsi masjid sebagai pusat peradaban masyarakat. BINA' AL UMMAH, 9(1), 33-40. Retrieved from https://garuda.ristekbrin.go.id/documents/detail/ 342301

Bustan, J., Divianto, D., \& Setiawan, H. (2017). Pelatihan dan pendampingan pembuatan proposal pengajuan kredit bank bagi para pedagang pasar tradisonal Sukawinatan Palembang. Comvice: Journal of community service, 1(1), 9-22. https://doi.org/10.26533/comvice.v1i1.146

Cholil, M. (2016). Revitalization of mosque role and function through development of "Posdaya" in the view of structuration theory. Research on Humanities and Social Sciences, 6(12), 43-51. Retrieved from http://www.iiste.org/Journals/index.php/RHSS/art icle/view/31454

Diana, R. (2019). Analisis aksesibilitas permodalan usaha mikro kecil di Provinsi Sumatera Barat. Jurnal Ekonomi dan Pembangunan, 27(1), 67-80. https://doi.org/10.14203/JEP.27.1.2019.67-80

DKM Masjid Attaqwa. (2020). Masjid At-Taqwa Lombok Timur Nusa Tenggara Barat. Retrieved May 4, 2021, from Https://dkm.or.id website: 
https://dkm.or.id/dkm/1369/masjid-at-taqwaselong-kab-lombok-timur.html

Faizaturrodhiah, N., Pudjihardjo, M., \& Manzilati, A. (2018). Peran institusi masjid sebagai pusat pemberdayaan sosial ekonomi masyarakat (Studi di Masjid Sabilillah Malang). IQTISHODUNA, 14(1), 1-14. https://doi.org/10.18860/iq.v0i0.4831

Hadiyanti, P. (2008). Strategi pemberdayaan masyarakat melalui program keterampilan produktif di PKBM Rawasari, Jakarta Timur. Perspektif Ilmu Pendidikan, 17(IX), 90-99. https://doi.org/10.21009/PIP.171.10

Haqqoni, A. D. (2020). Sistem pelayanan kesehatan poliklinik Masjid Al-Falah Surabaya. Tadbir: Jurnal Manajemen Dakwah, 5(3), 255-262. https://doi.org/10.15575/tadbir.v5i3.2020

Ilmi, F. W., \& Alhakim, M. I. A. (2020). Peran masjid dalam pemberdayaan ekonomi dan sosial umat di tengah pandemi Covid-19, Studi Kasus: Masjid AlMizan Griya Tahunan Indah Jepara. Community Development: Jurnal Pengembangan Masyarakat Islam, 4(1), 11-20. https://doi.org/10.21043/cdjpmi.v4i1.9517

Jannah, N. (2016). Revitalisasi masjid di era modern (studi terhadap peranannya di era modern). Journal Analytica Islamica, 5(1), 125-148. Retrieved from http://jurnal.uinsu.ac.id/index.php/analytica/articl e/view/483

Kuznetsova, I., \& Round, J. (2014). Communities and social care in Russia: The role of Muslim welfare provision in everyday life in Russia's Tatarstan region. International Social Work, 57(5), 486-496. https://doi.org/10.1177/0020872814536417

Machfudz, M., \& Kamila, N. (2019). Empowerment of small businesses through the implementation of qardhul hasan financing. Journal of Socioeconomics and Development, 2(2), 99-106. https://doi.org/10.31328/jsed.v2i2.1077

Martens, S. (2014). Muslim charity in a non-muslim society-the case of Switzerland. Journal of Muslims in Europe, 3(1), 94-116. https://doi.org/10.1163/22117954-12341278

Mohsin, M. I. A. (2013). Potential of zakat in eliminating riba and eradicating poverty in muslim countries. European Journal of Business and Management, 5(11), 114-126. Retrieved from https://iiste.org/Journals/index.php/EJBM/article/ view/5429

Musahadi. (2018). The role of mosque and khutba in socio-economic development of Indonesia: Lessons from Kauman Mosque in Central Java.
Global Journal Al Thaqafah, 8(2), 55-66. Retrieved from

http://www.gjat.my/gjat122018/GJAT1220185.pdf

Nasrulloh, A. A. (2020). Pengembalian fungsi baitul mal wa tamwil melalui strategi penyelesaian masalah rentenir di Tasikmalaya. Amwaluna: Jurnal Ekonomi dan Keuangan Syariah, 4(1), 7595. https://doi.org/10.29313/amwaluna.v4i1.5271

Omar, A. R. C., Hussin, M. Y. M., \& Muhammad, F. (2017). Perniagaan sosial menerusi aktiviti ekonomi masjid. Journal of Global Business and Social Entrepreneurship (GBSE), 1(1), 39-46. Retrieved from http://gbse.com.my/v1no1jan17/Paper-5-BM-.pdf

Pierce, L. (2014). A rhetoric of traumatic nationalism in the Ground Zero mosque controversy. Quarterly Journal of Speech, 100(1), 53-80. https://doi.org/10.1080/00335630.2014.888461

Rahim, A. (2018). The Empowerment strategy of the traditional fisherman's wives in the coastal area of Barru Regency, South Sulawesi. Journal of Socioeconomics and Development, 1(1), 1-6. https://doi.org/10.31328/jsed.v1i1.515

Rahoyo, \& Nss, R. L. P. (2019). Bank keliling pemburu rente dan involusi usaha pedagang pasar. Solusi, 17(4). https://doi.org/10.26623/slsi.v17i4.1778

Richter, R. (2019). Rural social enterprises as embedded intermediaries: The innovative power of connecting rural communities with supra-regional networks. Journal of Rural Studies, 70, 179-187. https://doi.org/10.1016/j.jrurstud.2017.12.005

Riwajanti, N. I., Muwidha, M., \& Candrawati, T. (2017). Mosque and economic development. Proceeding The First Annual International Conference on Islam and Civilization (UMM-AICIC 2017), 1, 124-129. Malang: Universitas Muhammadiyah Malang. Retrieved from http://researchreport.umm.ac.id/index.php/AICIC/article/view/19 35

Sager, R. (2014). Claiming society for god: Religious movements and social welfare. Sociology of Religion, 75(1), 177-178. https://doi.org/10.1093/socrel/sru009

Saint-Blancat, C., \& Friedberg, O. S. di. (2005). Why are mosques a problem? Local politics and fear of islam in Northern Italy. Journal of Ethnic and Migration Studies, 31(6), 1083-1104. https://doi.org/10.1080/13691830500282881

Siam, E. (2012). The Islamist vs the islamic in welfare outreach. IDS Bulletin, 43(1), 87-93. 
https://doi.org/10.1111/j.1759-

5436.2012.00294.x

Sochimin. (2016). Manajemen keuangan masjid berbasis pemberdayaan ekonomi umat. El-Jizya: Jurnal Ekonomi Islam, 4(1), 119-150. https://doi.org/10.24090/ej.v4i1.2016.pp119-150

Utama, R. D. R., Fitrandasari, Z., Arifin, M., \& Muhtadi, R. (2018). Can mosque fund management for community economic empowerment? An exploratory study. IJIBE (International Journal of Islamic Business Ethics), 3(2), 451-457. https://doi.org/10.30659/ijibe.3.2.451-457

Wulandari, S. (2017). Optimizing fund management of mosque cash for economic empowerment of people. 258-262. Atlantis Press. https://doi.org/10.2991/icpsuas-17.2018.54 